\title{
Humerus distal metafizyel eklem-dışı kırıkları
}

\section{Extra-articular metaphyseal fractures of distal humerus}

\author{
Neslihan Aksu',2, Zekeriya Uğur Işıklar ${ }^{2}$ \\ ${ }^{1}$ İstanbul Bilim Üniversitesi Tıp Fakültesi, Ortopedi ve Travmatoloji Anabilim Dalı, İstanbul \\ ${ }^{2}$ Florence Nightingale Hastanesi, Ortopedi ve Travmatoloji Bölümü, İstanbul
}

Distal humerus kırıkları nadir ancak tedavisi deneyim gerektiren yaralanmalardır. Bu kırıklar daha çok osteoporotik yaşlı nüfusta düşme sonucu oluşurlar. Kırık, fleksiyondaki dirsek üzerine düşüldüğünde humerusun direkt darbe almasıyla veya açık kol üzerine düşme sonucu gelişen aksiyel yüklenme ile oluşur. Genç erişkinlerde oluşma mekanizması ise daha çok ateşli silah yaralanması, trafik kazası gibi yüksek enerjili travmalardır. Üç boyutlu geometrisi, yetersiz subkondral ve spongiyöz kemik stoğu, dirsek eklemine yakın oluşu ve geçmişte bu bölge anatomisine uygun plak vida sistemlerinin olmayışı bu kırıkların tedavisini zorlaştıran nedenler olmuştur. Cerrahi olarak tedavi edilen kırıklarda kaynamama, yanlış kaynama ve eklem sertliği sık gözlenmektedir. Tedavi sonrası hastalara erken hareket ve gerekli rehabilitasyon uygulanamadığı takdirde hareket ve fonksiyonel kısıtlılık kaçınılmazdır. Humerus distal uç kırıkları sonuçları itibariyle günümüzde hala komplikasyon oranının yüksek olabildiği kırık tiplerindendir. Bunun en büyük nedeni ise sınıflama, anatomi, tedavi seçenekleri, ameliyat sonrası rehabilitasyon gibi konularda bilgi ve deneyim eksikliğidir. Yetersiz ve sağlam olmayan bir cerrahi tespitin revizyonu ilk ameliyata göre her zaman daha zordur. Fonksiyonel bir dirsek için erken aktif hareket, bunun için de güvenilir rijid tespit gereklidir. İyi bir cerrahi teknikle yapılan rijid bir tespit ve hasta uyumuyla iyi ve mükemmel klinik fonksiyonel sonuç elde edilebilir.

Anahtar sözcükler: humerus kırıkları; bağlar, eklem; kilitli plak

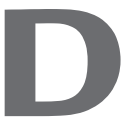

istal humerus kırıkları nadir ancak tedavisi deneyim gerektiren yaralanmalardır. Üç boyutlu geometrisi, yetersiz subkonral ve spongiyöz kemik stoku, açısal olarak sabit plak vida sistemlerinin olmayışı geçmişte bu kırıkların özellikle eklemi ilgilendirdiğinde cerrahi tedavisinde sorunlara yol açmış, hatta bu kırıkların cerrahi olarak tedavisinin yapılmaması önerilmiştir.
Extra articular fractures of the distal humeral fractures are rare; however, these injuries require experienced treatment. These kind of fractures in the osteoporotic elderly population are caused generally by falls. The fracture occurs when humerus receives a direct impact while stepping on the elbow in flexion or by axial loading on open arms during a fall. The fracture mechanisms in young adults are mostly the result of gunshot wounds or high-energy traumas due to traffic accidents. Their three-dimensional geometry and being very close to the elbow joint, inadequate subchondral and cancellous bone stock of the patient, and the lack of convenient platescrew systems suitable for the anatomy of that region has been complicating factors for the treatment of these fractures in the past. Nonunion, malunion and stiffness in the elbow joint are common in the surgically treated fractures of this kind. Functional limitations are inevitable if early motion is neglected and proper rehabilitation exercises are not applied after the treatment. As a result, the treatment of the distal humerus fractures are still the fracture type with high complication rates nowadays. The primary reason is lack of knowledge on the classification, anatomy, treatment options, postoperative rehabilitation, and insufficient surgical experience. Surgical revisions are always more difficult after an insufficient and unstable fixation of the fracture primarily done. A reliable rigid fixation that enables early active motion is necessary for a functioning elbow. Clinically excellent functional results can be achieved by rigid fixation with a good surgical technique and patient compliance.

Key words: humeral fractures; ligaments, articular; locking plate

Cerrahi olarak tedavi edilen kırıklarda kaynamama, yanlış kaynama ve eklem sertliği sık gözlenmiş ve bu komplikasyonları tedavi etmede gerekli bilgi olmaması nedeni ile başarısızlık kaçınılmaz olmuştur. [1] Tedavi sonrası hastaların büyük çoğunluğuna erken hareket ve gerekli rehabilitasyon uygulanamadığı için hareket ve fonksiyonel kısıtlılık sık gözlenmiştir. ${ }^{[1]}$

- Illetişim adresi: Doç. Dr. Neslihan Aksu, Abide-i Hürriyet Caddesi No: 166, Şişli, İstanbul

Tel: 0212 - 3756565 / 5224 e-posta: neslihan.aksu@gmail.com

- Geliștarihi: 10 Ocak2014 Kabul tarihi: 10 Ocak2014 
Son 10 yılda bu bölgenin anatomik ve fonksiyonel yapısının daha iyi anlaşılması ve özellikle tespit yöntemlerinde anatomik ve kilitli plak teknolojisindeki gelişmeler geçmişteki olumsuz deneyimlerimizin aksine başarılı sonuçlar elde etmemizi sağlamıştır. İleri yaş grubunda gözlenen osteoporotik kırıklarda bile başarılı sonuçlar elde edilebilmiş, hastaların \%90 oranında yaralanma öncesi hayat kalitesine ulaşmaları sağlanmıştır. ${ }^{[1]}$

Humerus distal uç kırıkları sonuçları itibariyle günümüzde hala komplikasyon oranının yüksek olabildiği kırık tiplerindendir. Bunun en büyük nedeni ise sınıflama, anatomi, tedavi seçenekleri, ameliyat sonrası rehabilitasyon gibi konularda bilgi ve deneyim eksikliğidir.

Nadir görülmekle birlikte daha çok osteoporotik yaşIı nüfusta düşme sonucu oluşurlar. Kırık, fleksiyondaki dirsek üzerine düşüldügüünde humerusun direkt darbe almasıyla veya açık kol üzerine düşme sonucu gelişen aksiyel yüklenme ile oluşur. Genç erişkinlerde oluşma mekanizması ise daha çok ateşli silah yaralanması, trafik kazası gibi yüksek enerjili travmalardır. ${ }^{[2]}$

Distal humerus kırıkları, tüm kırıkların \%2'sini ve humerus kırıklarının yaklaşık üçte birini oluştururlar. Yaş ve cinsiyet göz önünde bulundurulduğunda bimodal dağılım gösterirler. Erkeklerde daha çok 12-19 yaşlar arasında görülürken, daha ileri yaşlarda görülme sıklığı azalmakta, 70 yaş ve sonrasında tekrar artmaktadır. Kadınlarda ise daha sıklıkla orta ve ileri yaşlarda görülmektedir. Özellikle genç nüfusta yüksek enerjili travmalar sonucu oluşmaları nedeniyle açık kırık ve diğer sistem yaralanmalarının görülme olasılığı yüksektir (Şekil 1). ${ }^{[2]}$

\section{ANATOMI}

$\mathrm{Bu}$ bölge anatomisinin iyi bilinmesi kırık tiplerinin daha iyi kavranmasını sağlar ve tedavinin planlanmasında hekime yardımcı olur. Humerus distali, uç

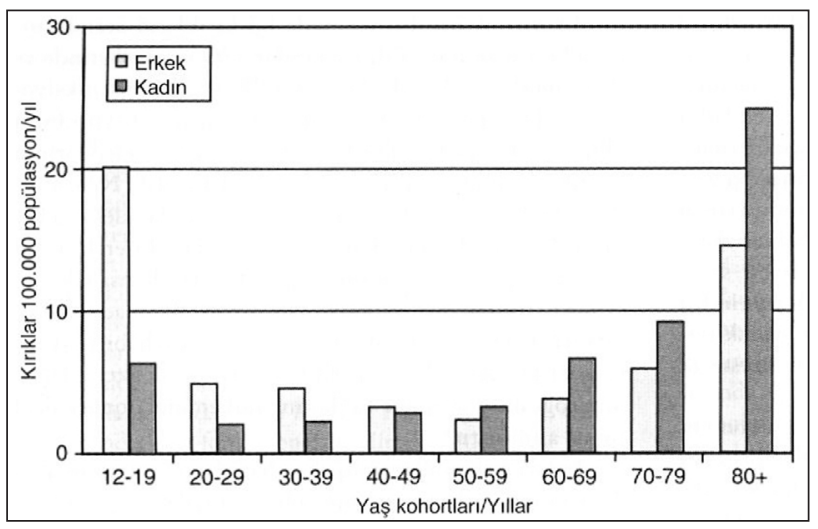

Şekil 1. Distal humerus kırıklarının yaş ve cinsiyete göre görülme sıklığı. kısımları kondiler olarak sonlanan iki kolon tarafından oluşturulur. Bu iki kolon troklea tarafindan birleştirilir. Aralarında, arkada olekranon fossa, önde ise koronoid fossayı oluşturan, ince bir kemik tabakası vardır.

Mediyal ve lateral kolonlar ve onları birleştiren troklea bir üçgene benzer ve bu üçgenin kenarlarından birinin zarar görmesi diğerinin stabilitesini de bozar.

Mediyal kolonun en uç kısmı mediyal epikondil, lateral kolonun en uç kısmı ise kapitellumdur. Mediyal kolon distale doğru gidip sonlanırken humerus cisminin uzun ekseni ile yaklaşık $40^{\circ}$, lateral kolon ile ise $20^{\circ}$ lik açı yapar.

Kapitellum ve troklea, distal humerus eklem yüzleridir. Troklea olekranon ile, kapitellum ise radius başı ile eklem yapar. Trokleanın iki kolonu birleştiren yapı olması nedeniyle ulnotroklear ekleme binen yükler humerusun her iki kolonuna, radyokapitellar ekleme binen yükler ise sadece lateral kolona aktarilır. Kapitellumun hemen üzerinde radyal fossa yeralır ve radius başının maksimum fleksiyonda yerleşmesi için uygun yapıdadır. Troklea üzerinde anteriorda koronoid fossa, posteriorda simetrik olarak olekranon fossa yer alır. Koronoid fossaya fleksiyon sırasında ulnanın koronoid çıkıntısı, olekranon fossaya ise ekstansiyon sırasında olekranonun en proksimal bölümü yerleşmektedir. ${ }^{[2]}$

Kondillerin eklem yapmayan bölümlerinde ön kol kaslarının yapıştığı çıkıntılar vardır. Lateral ve mediyal epikondil olarak adlandırılan bu çıkıntılardan lateraldekine ön kolun ekstansör-supinatör kasları ve lateral kollateral bağ, mediyaldekine ön kolun fleksörpronatör kasları ve mediyal kollateral bağ yapışır. Bu bölgeler avulsiyon kırıklarının görülebildiği yerlerdir. Mediyal epikondilin hemen arkasından unlar sinir kendisine ait oluktan geçmektedir. Epikondillerin hemen proksimalinde kalan bölge suprakondiler bombe olarak adlandırılır; bu bölge ve distalinde kalan kısım distal humerus olarak adlandırılmaktadır.

Ön-arka grafide epikondillerden geçen, humerusun en geniş alanına eşit uzunlukta çizilen kare içinde kalan bölge kırıkları distal humerus kırıkları olarak adlandırılır (Şekil 2a). Eğer kırık bu bölgenin proksimaline de uzanıyorsa majör parçasının yerleşimine göre kırık adlandırılması yapılmaktadır. ${ }^{[2]}$

Distal humerus yaklaşık $30-40^{\circ}$ öne eğimlidir. Kemiklere tek tek bakıldığında ise kapitellumun $30-40^{\circ}$, trokleanın ise $25^{\circ}$ öne açılandığı görülür. Humerus, distale doğru gidildikçe koronal planda genişler ve yassılaşır. Bu genişleme epikondiller seviyesinde en üst düzeye ulaşır. Sagittal planda ise humerus proksimalden distale doğru daralmaktadır. Aksiyel planda trokleanın ekseni, mediyal ve lateral epikondillere göre $3-8^{\circ}$ dış rotasyondadır (Şekil $2 b$ ). ${ }^{[2]}$ 

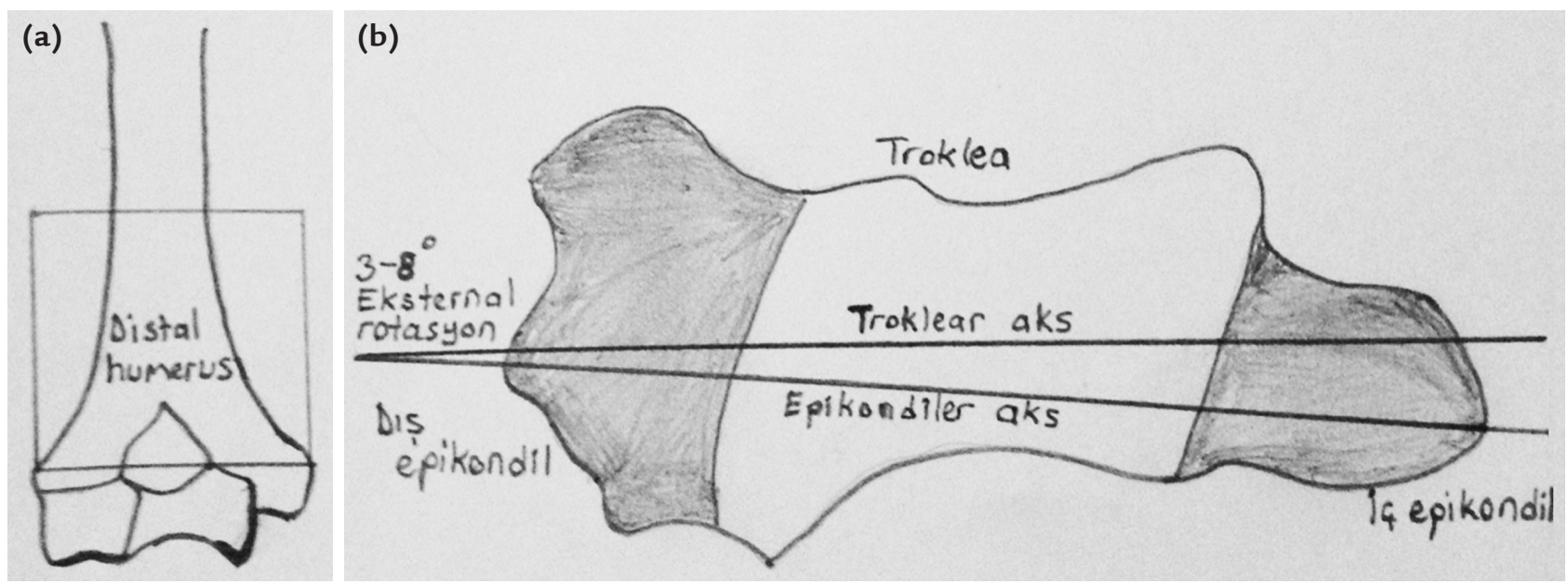

Şekil 2. a, b. Epikondilleri birleştiren çizgi karenin bir kenarı olarak kabul edilirse, karenin içerdiği alan distal humerusu simgeler (a). Aksiyel planda trokleanın ekseni, mediyal ve lateral epikondillere göre $3-8^{\circ}$ dış rotasyondadır (b). ${ }^{[2]}$

Humerusun distal eklem yüzü, uzun aksına göre 4-8 ${ }^{\circ}$ valgustadır (Şekil 3a). ${ }^{[2]}$ Buna taşıma açısı denir. Ortalama $11-17^{\circ}$ kadardır. Trokleanın mediyal çıkıntısı lateraldekine göre daha büyüktür. Bunun yanında troklea koronal planda kapitelluma göre daha distalde sonlanır. Bu nedenlerden dolayı dirsek ekstansiyonda, valgus pozisyonundadır. Humerus distalinin valgusta olması ile birlikte olekranonun ulnaya doğru açılması, dirsek tam ekstansiyonda iken, $20^{\circ}$ ye kadar ulaşabilen taşıma açısı oluşturur. Dirsek fleksiyona getirildiğinde ise kapitellumun anteriora daha fazla açılanması nedeniyle dirsek varus pozisyonunu alır. Yandan bakıldığında kapitellum ve troklea humerusun uzun ekseninin önündedir. Kapitellumun rotasyonel merkezi humerus aksının 12-15 mm kadar önünde yer alır. Çekilecek dirsek yan grafisinde humerusun ön korteksinden çizilen çizgi kapitellumun merkezinden geçer. Yine radiusun uzun ekseninden çizilen çizgi de kapitellumun merkezinden geçmelidir. ${ }^{[2]}$ Bu durum dirseğin fleksiyon derecesinden bağımsızdır (Şekil 3b). Bu özelliklerin bilinmesi distal humerus kırıklarının tanısında bize yardımcı olur, kırık tipini ve şeklini anlamamızda yol gösterir.

\section{Dolaşım}

Kemik dışı dolaşım mediyalde, lateralde ve posteriorda üç ark olarak organize olmuş zengin bir kan tedariki alır; ${ }^{[1]}$ mediyal superior kollateral, inferior
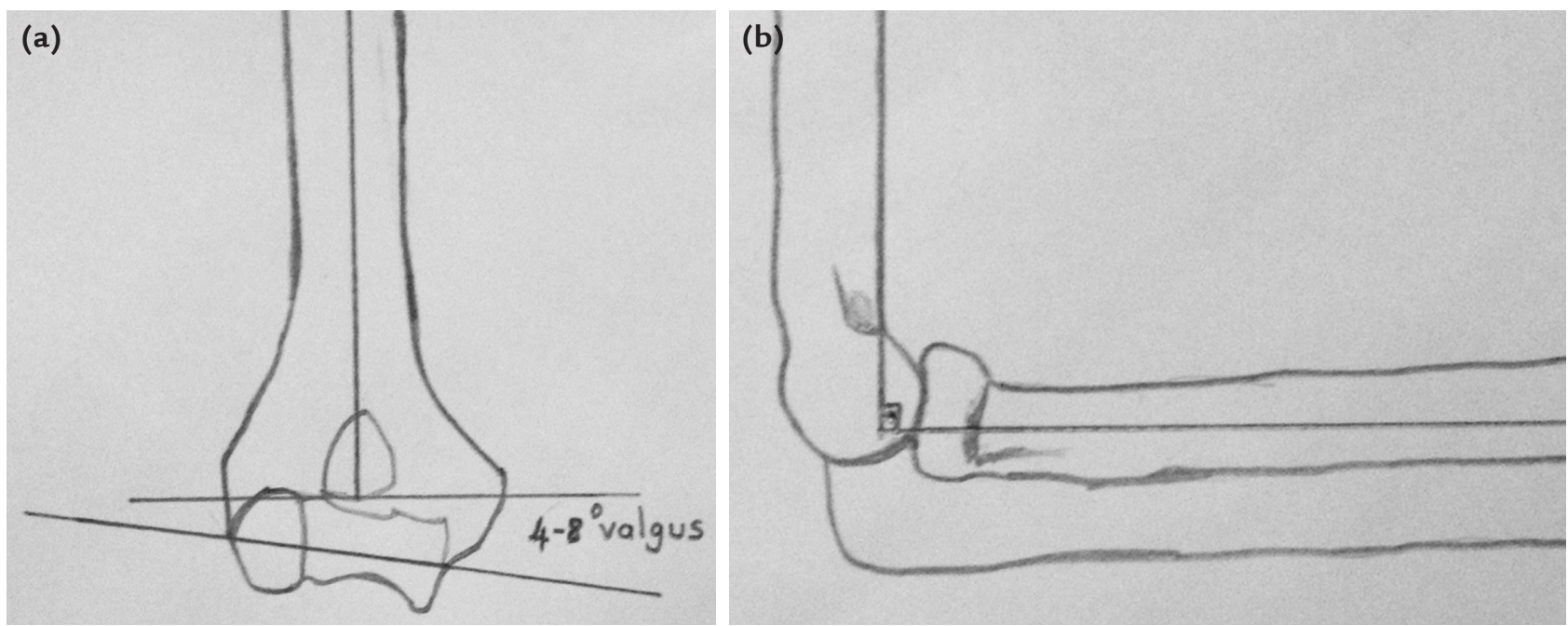

Şekil 3. a, b. Humerusun distal eklem yüzü, uzun aksına göre $4-8^{\circ}$ valgustadır (a). Radiusun uzunlama aksında ve humerusun anterior korteksi boyunca çizilen çizgiler kapitellumun merkezinden geçer (b). 
kollateral ve posterior rekürren arterlerden oluşur. Lateral ark radyal ve orta kollateral, interosseöz ve radyal rekürren arterlerden ve posterior ark orta kollateral artere ilaveten mediyal ve lateral arkların her ikisinden katkı alır (Şekil 4. a, b).

Kemik içi kan dolaşımı organizasyon olarak segmenter olup üç arktan çıkan besleyici perforatörlerdendir. Kapitellum ve troklea lateral yüzü radyal rekürren, radyal kollateral ve interosseöz rekürren arterlerden çıkan posterior perforatör damarlar tarafından beslenirken, trokleanın mediyal yüzü inferior ulnar rekürren arterden çıkan çevresel (circumferential) vasküler halkadan beslenir. Distal humerus mediyal ve lateral yüzlerinin kan kaynakları arasındaki sınır bölgesi aşikardır.

Distal humerus bu nedenle zengin anastomozlu kan dolaşımına sahiptir ve osteonekroz ve iyileşme ile ilgili sorunlar bu yüzden göreceli olarak nadirdir. Karmaşık kapalı distal humerus kırıklarının redüksiyon ve internal tespiti sırasında tamamiyle devaskülarize olan fragmanların saklanması büyük ise ve rekonstrüksiyon stabilitesine katkıda bulunuyorsa uygundur.

\section{SINIFLAMA}

Son 30 yıl içinde tedavi seçimi, konservatif yöntemlerden cerrahi girişimlere doğru değişim gösterirken, cerrahi girişim şekli, tedavi seçimi ve cerrahi tespit yöntemlerini belirlemede bize yol gösterecek, bilimsel yayınlarda bildirilen sonuçların daha uyumlu olmasına yardımcı olacak sınıflama sistemlerine gerek duyulmuştur. Bu kırıklar 1970 yılı öncesinde anatomik bölgeye göre, kondiler, epikondiler, suprakondiler gibi terimler kullanılarak ve yer değişikliğine göre sınıflandırıldı. ${ }^{[2]}$

ilk kapsamlı sınıflamayı AO (Association for Osteosynthesis) kırık sınıflama çalışma grubu tanımlamıştır ${ }^{[3]}$, daha sonra OTA (Orthopedic Trauma Association) ile birlikte en kapsamlı ve gelişmiş sınıflama sistemi geliştirilmiştir. ${ }^{[17]}$ Her ikisi de eklemi içermesi derecesine göre alt sınıflama ile birlikte $A B C$-sayısal (alphanumeric) sistemi kullanır. Tip A kırıklar eklemdışıdır, Tip B kırıklar eklemi kısmen içerir; Tip C ise eklemin tümünü ilgilendirir (Şekil 5).
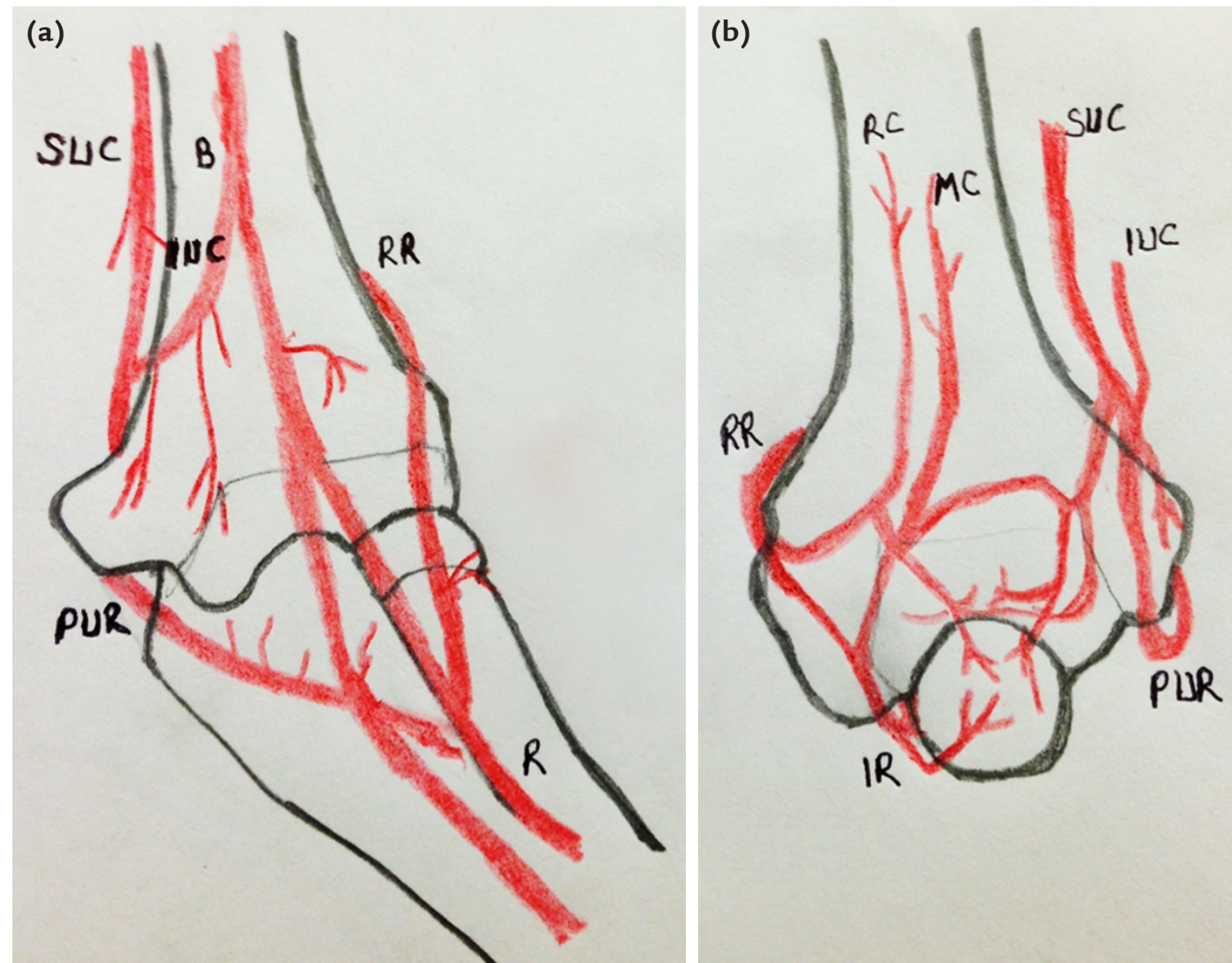

Şekil 4. a, b. Distal humerusun kan dolaşımı: Anterior görünüm (a). Posterior görünüm (b). SUC, superior ulnar kollateral arter; B, brakiyal arter; IUC, inferior ulnar kollateral arter; RR, radyal rekürren arter; PUR, posterior ulnar rekürren arter; R, radyal arter; RC, radyal kollateral arter; MC, orta kollateral arter; IR, interosseöz rekürren arter. ${ }^{[2]}$ 


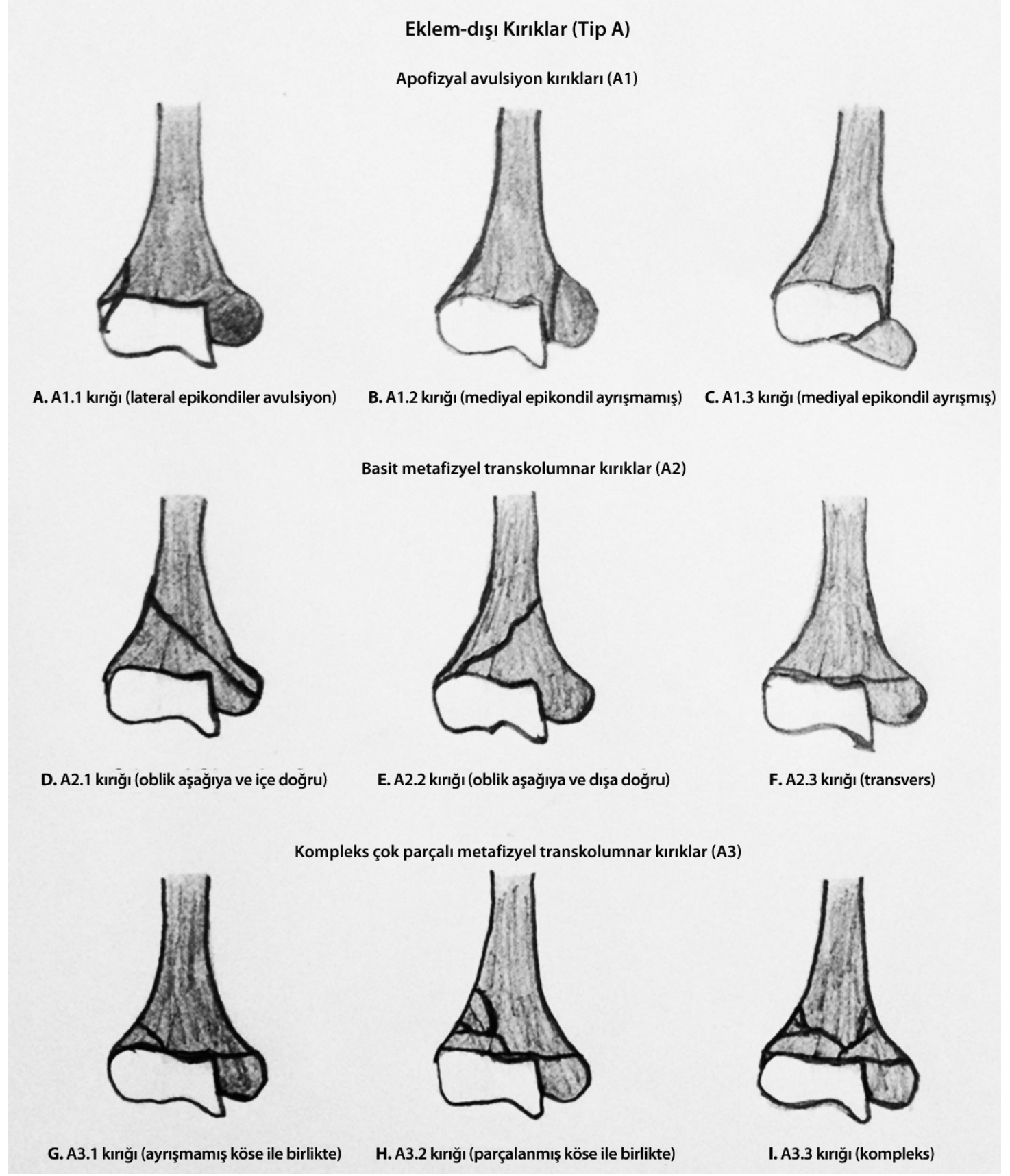

Şekil 5. Distal humerus kırıklarında AO sınıflaması.

Diğer en son sınıflama sistemi Jupiter ve arkadaşları tarafindan ortaya konmuştur. ${ }^{[1]} \mathrm{Bu}$ "iki kolon ve kravat arkı" dirsek kavramını temel alır. Dirseğin kolonları AO sisteminde tarif edilmiş olan kondillere benzer. Sınıflama ayrıca kırık seviyesinin ayrımını sağlar, bu rekonstrüktif girişimin karmaşıklığının önemli bir belirleyicisidir.

Her iki sınıflama arasında birçok benzerlik vardır; $\mathrm{AO}$ sisteminin avantajı, her yerde hazır olması sayesinde ana alt bölümlerin kolaylıkla hatırlanabilir ve anlaşılabilir olmasıdır. Jupiter sınıflaması daha karmaşıktır ve tedavi amacıyla eklem yüzü kırıklarının değişik tiplerinin ayrımını sağlamaz. Her ikisinde de gözlemci hatası doğrulamada noksanlık gibi eksiklikler var olup hiçbiri kırık fragmanların yer değiştirme derecesini bir faktör olarak dikkate almaz. ${ }^{11]}$ Sonuçta, Jupiter sınıflamasının rekonstrüksiyon sorunları için daha iyi bir rehber sağ|ıyabileceği öngörülmüştür. 


\section{TANI}

Dikkatli bir fizik muayene, tanı koymadaki en önemli adımdır. Hasta travma sonrası başlayan ağrı, şişlik ve ekstremitesini hareket ettirememe yakınmaları ile başvurur. Kırığın yeri ve ayrışma durumuna göre deformite ve ekstremitede kısalık görülebilir. Açık kırıklar açısından da dikkatli olmak gerekir. Tespit edilmesi durumunda, tedaviye tetanoz profilaksisi ve antibiyoterapi de eklenmelidir.

Muayene sonrası iki yönlü dirsek radyografileri çekilmelidir. İlk aşamada ön-arka ve yan grafiler yeterli olacaktır. Gerekli görüldüğünde oblik grafilerle kırığın durumu hakkında ek bilgiler edinilebilir. Şüphede kalınan durumlarda karşılaştırma amacıyla sağlam ekstremitenin grafileri de çekilebilir. Ön-arka grafiler çekilirken dirsek tam ekstansiyona, ön kol supinasyona getirilip ışınlar dirseğe dik olacak şekilde yönlendirilir. Lateral grafi çekilirken, dirsek eklemine $90^{\circ}$ fleksiyonda iken ön kola, başparmak tavanı gösterecek şekilde yukarı bakarken pozisyon verilmelidir. Bunun yanında fleksiyonda ön-arka grafi çekilebilir. Bunun için dirsek $30-40^{\circ}$ kadar fleksiyona getirilip röntgen ışıkları humerus distaline dik olarak gönderilmelidir. Böylece olekranonun süperpozisyonu önlenir. Buna ek olarak ön kola traksiyon uygulanarak dirsek tam ekstansiyonda iken çekilen ön-arka grafiler kırık parça sayısı ve ekleme uzanımla ilgili sağlıklı bilgiler verir. Ancak hastanın ağrısı nedeniyle bu grafileri uygun pozisyonda çekmek her zaman mümkün olmayabilir. $\mathrm{Bu}$ durumda uygun analjezi veya sedasyon altında grafiler çekilebilir. Eşlik edebilecek yaralanmaların atlanmaması amacıyla aynı taraf ön kol ve humerus proksimalini gösteren grafilerin de çekilmesi gerektiği unutulmamalıdır.

Genel olarak humerus distal kırıklarının tanısını koymak kolaydır. Ancak bazen, kırık parçaları arasında ayrışma olmaması durumunda tanı koymak zorlaşabilir. Bazen de direkt radyografiler ile kırığın şekli ve tipi tam olarak belirlenemeyebilir. Normal eklem kapsülünün etrafında ince bir yağ dokusu tabakası vardır. Kırık oluşması durumunda biriken kırık hematomunun eklem kapsülünü germesi ve buna bağlı olarak direkt grafide gözüken yağ gölgesinin yer değiştirmesiyle radyografide tam olarak seçilemeyen kırıklar tanınabilir. Bu durum yağ yastıkçığı bulgusu (fat pad sign) olarak adlandırılır.

Distal humerus kırıklarında, özellikle ekleme uzanım gösteren kırıklarda bilgisayarlı tomografi (BT) tedavi kararı alınırken oldukça faydalı olabilmektedir. Özellikle 2-3 mm'lik kesitlerle çekilen BT'lerde üç boyutlu rekonstrüksiyon ile eklem düzeyindeki kırıklar daha sağııklı olarak değerlendirilir. Her ne kadar rutin olarak kullanılmasa da BT, tanı koymada zorlanılan durumlarda tercih edilebilecek bir görüntüleme yöntemidir. ${ }^{[2]}$

Humerus distal uç kırıkları, bu bölgeden geçen tüm nörovasküler yapılara zarar verebilir. Sinirlerde tam kat kesi olabileceği gibi kırık parçaları arasında sıkışma sonucunda hastada nörolojik defisit gelişebilir. Bu nedenle hastanın nörolojik muayenesi dikkatli bir şekilde yapılmalı, el ve ayak parmaklarında parestezi olup olmadığı ve parmakların hareket ettirilip ettirilemediği kontrol edilmelidir. Ancak burada en önemli sorun, hastanın ağrı nedeniyle istenilen hareketleri yapamamasıdır. Bu durum sinir yaralanması açısından tanı koymayı güçleştirir. Benzer durum damarsal yapılar içinde geçerlidir. Her ne kadar çok sık olmasa da, vasküler yaralanmalar kırığa eşlik edebilir. Muayene sırasında kırık distalinde nabızların palpe edilmemesi, tırnak yatağından bakılan kapiller dolumun yavaşlaması, el ve ön kolda solukluk gibi damarsal yapıların yaralanma işaretleri açısından dikkatli olunmalıdır. Ancak bazen brakiyal arter tam kat kesilerinde bile kollateral damarlar nedeniyle ön kolun dolaşımı korunabilir. Bu nedenle şüphe duyulması durumunda mutlaka damar cerrahisi konsültasyonu istenmeli, gerekli durumlarda Doppler ultrasonografi veya arteriyogram yapılmalıdır. Parmakların özellikle pasif ekstansiyon hareketleri sırasında ön kolda aşırı ağrı hissedilmesi kompartman sendromu açısından uyarıcı olmalıdır. ${ }^{[2]}$

\section{TEDAVi}

Her kırığın tedavisinde önemli olan hastaya uygun bir tedavi seçilmesidir. ${ }^{[22]}$ Tedavide amacımız tedavi sürecinde komplikasyonsuz bir şekilde ağrısız, tam hareketli ve fonksiyonel bir dirsek eklemi elde etmektir. Kırığın ciddiyeti arttıkça, hastanın bu hedeflere ulaşması daha zordur. Hastalar bu konu hakkında önceden bilgilendirilmelidir. Hekim ve hasta ileride yaşanabilinecek eklem sertliği, hareket kısıtılı̆̆ı, deformite ve geçmeyen ağrılar gibi sonuçlara hazırıklı olmalıdır. Eklem dışı distal humerus kırıkları konservatif olarak ve cerrahi olarak tedavi edilebilir. Eklem dışı kırıklar, eklem içi kırıklarla karşılaştırıldığında daha iyi prognoza sahiptir. ${ }^{[2]}$ Distal humerus kırığı olan çoğu hasta cerrahi olarak tedavi edilebilse de tıbbi komorbiditeye sahip olan hastalarda konservatif tedaviyi seçmek zorunda kalabiliriz. Radyolojik olarak kırı̆ı̆ın ciddiyetinden bağımsız olarak ileri yaşlarda ve düşük yaşam beklentisine sahip hastalarda cerrahiden uzaklaşmak gerekir. ${ }^{[2]}$

\section{Konservatif tedavi}

Eklem dışı distal humerus kırıklarında tedavi kararı verirken öncelikle kırığın tipi ve yerleşimi, hastanın 
yaşı, hastanın eşlik eden hastalıkları, ilave damar-sinir yaralanması ve yumuşak doku hasarı göz önünde bulundurulmalıdır. Güncel olan, ayrışmış distal humerus kırıklarının cerrahi tedavi edilmesidir. ${ }^{[2]}$ Uzun kol alçı veya atel, uzun kol sirküler alçı, fonksiyonel breys veya iskelet (olekranon) traksiyonu konservatif tedavi seçeneklerimizdir. Bu seçenekler hasta yaşı, hastanın kırık tipi, yumuşak doku yaralanması ve hekimin deneyimine göre değişebilir. Kırık olan ekstremite alçıya alınırken kırığın proksimal ve distalinde stabilite sağlanmalıdır. Atel yapılacaksa ekstremitenin posterioruna yerleştirilmelidir. Dirsek $90^{\circ}$ fleksiyonda ve ön kol nötral durumda tespit sağlanır. Lateral epikondil kırı̆ı̆ında ön kol supinasyonda, mediyal epikondil kırığında ise pronasyonda iken tespit edilir. ilk bir ay dizilim haftalık grafi kontrolleriyle takip edilir. Radyolojik olarak 6-10 haftada kaynama görüldüğünde tedavi sonlandırılır. ${ }^{[2]}$ Traksiyon metodunda hastanın dirseği aşırı şiş ise cerrahiye kadar beklenir veya cerrahi tedavi düşünülmeyen hastalarda olekranondan geçen bir adet tel ve tele bağlanan bir ağırlık ile kırık redükte edilmeye çalışılır. Üç-dört haftalık traksiyon sonunda, yeterli kallus dokusu görüldükten sonra alçılamaya geçilebilir. ${ }^{[1]}$ İskelet traksiyonunda komplikasyon olarak uzamış yatış süresi sayılabilir. Modern tekniklerle birlikte iskelet traksiyonu tarihi yerini almıştır ve artık kullanılmamaktadır.

Ayrışmamış kırıklarda konservatif tedavi tercih edilebilir. Cerrahi tedavi uygulanamayacak yaşlı hastalar ve eşlik eden sağlık sorunları olan hastaların ayrışmış kırıklarında redüksiyon sonrası eğer dizilim elde edilebilirse ve stabil eklem dışı distal humerus kırıkları dizilim sağlandığı sürece konservatif tedavi edilebilir. Bu hastalar 3-4 hafta boyunca haftalık seri radyografi kontrolleri ile yer değiştirme ve açılanma açısından izlenmelidir. Politravmalı hastada erken hareket verebilmek için cerrahi tedavi seçilebilirken, ileri yaş osteoporotik ve sağlık sorunları olan hastalarda konservatif tedavi daha uygun olacaktır. ${ }^{[1]}$

Jawa ve arkadaşları 40 eklem dışı $1 / 3$ distal humerus kırığı olan hastanın 19'unu plak ve vida tespiti ile, 21 'ini fonksiyonel breys ile en az 6 ay takip etmişlerdir. ${ }^{[5]}$ Fonksiyonel breys kullanan hastalarda cilt problemleri ve omuz ile dirsek fonksiyonlarını etkilemeyen açısal ve translasyonel dizilim kusurları görülmüş, kaynamama ise hiç görülmemiştir. ${ }^{[5]}$ Cerrahi tedavi edilen hastalarda tam stabilite elde edilip erken eklem hareketlerine başlanmış fakat 19 hastadan 3'ünde iyatrojenik ameliyat sonrası radyal sinir felci gelişmiş ve 3 hastada 4 ek cerrahi yapılmak zorunda kalınmıştır. ${ }^{[5]}$ Sarmiento ve arkadaşları 69 eklem dışı distal humerus kırı̆ıııı fonksiyonel breys ile tedavi etmiş, 3 hastada kaynamama bildirmiştir. Elli altı hastada varus açılanması, 28 hastada $10^{\circ}$ 'den fazla açılanma görülmüş, 15 hastada dirsek fleksiyonu $5-25^{\circ}$ azalmış, 14 hastada dirsek ekstansiyonu $5-25^{\circ}$ kısıtlanmıştır. ${ }^{[2]}$

Bu tip kırıkları tedavi ederken öncelikli amaç dirsek eklemini mümkün olduğu kadar geniş hareket açıklığına kavuşturmak ve ağrısız bir dirsek elde etmektir. Cerrahi tespit stabiliteyi arttırır, erken hareketi sağlar ve kırığın ayrışma ihtimalini azlatır.

\section{Mediyal ve lateral epikondil kırıkları (AO/OTA Tip A1 kırıklar)}

Mediyal ve lateral epikondil kırıkları genelde bikolumnardır ve eklem içi kırıklar ile sık görülmekle birlikte erişkinde izole epikondil kırıkları oldukça nadir görülür. Tüm distal humerus kırklarının \%15 kadarını oluşturur; ${ }^{[6]}$ eklem ve kapsül dışı olan kırıklardır. Mediyal epikondil kırığı daha sık görülür ve çoğu eklem içine uzanım gösterir. Eğer kırılan fragman ayrışırsa, fleksör tendonların anterior ve distale doğru çekmesi ile yer değiştirir. Mediyal kollateral bağın buradaki yapışma yerinden dolayı dirsek stabilizasyonu bozulabilir ve beraberinde çıkık da görülebilir. Lateral epikondil kırıklarında ulnar kollateral bağ eklem stabilitesini devam ettirir ve çıkık oluşmaz. Deplase olan mediyal fragman dirsek çıktığında eklem içine kaçabilir. Çocuklarda daha çok çıkık görülür; erişkinlerde ise mediyal epikondil kırıklarının 1/4'ünde eşlik eden çıkık görülür. ${ }^{[6,7]} \mathrm{Bu}$ kırıklar genç erişkinlerde daha çok spor kazaları sırasında ekstansiyondaki ön kol ve ileri doğru uzanan elin üzerine düşme sonucu görülürler. Özellikle bilek güreşi sırasındaki aşırı fleksiyon ve sonrasında rakibin fleksör tendonları valgusta germesi nedeniyle mediyal epikondilde izole avulsiyon kırığı oluşturabilir. ${ }^{[8]}$

\section{Tedavi}

Eğer her iki epikondilde de ayrışma yoksa veya 1 $\mathrm{cm}$ 'den az varsa, 2 haftalık atel uygulaması ile immobilize edilir. Mediyal epikondil kırıklarında, fleksör tendonlarının gevşemesi ve ayrışma riskinin azalması için dirsek $90^{\circ}$ fleksiyonda, ön kol pronasyonda ve el bileği fleksiyonda tutulur. ${ }^{[9]}$ Lateral epikondil kırıklarında dirsek $90^{\circ}$ fleksiyonda, ön kol supinasyonda ve el bileği hafif ekstansiyonda olmalıdır. Ayrışma $1 \mathrm{~cm}$ 'den fazla ise ve eklem içine kaçan fragman olduğunda tedavi cerrahidir; açık yerleştirme ve vida ile içsel tespit yoluyla tedavi edilir. ${ }^{[10]}$ Büyük kemik fragmanları varsa pullu çektirme vidası ile tedavi gerekir. Daha küçük fragmanlarda Ktelleri ile tespit yeterli olur. Çok parçalı ve proksimale uzanan kırıklarda plak ile tespit stabiliteyi arttırarak erken harekete izin verir. Cerrahi öncesi ulnar sinir disfonksiyonu olan hastalarda ulnar sinir eksplore edilmeli, dekomprese edilip anteriora transpoze edilmelidir. 


\section{Transkolumnar kırıklar (AO/OTA Tip A2 ve A3 kırıklar)}

Distal metafizyel, lateral kolon ve mediyal kolonu tutan ve eklem içine uzanım göstermeyen kırıklardır. Bu tip kırıklar epifiz hattı kapandıktan sonra çok nadir görülürler. Genelde çocuklarda sık ve yaşlı erişkinlerde basit düşmeler sonucunda görülür. AO sınıflamasında Tip $A 2$ ve A3 kırıklar olarak geçer. Tip A2 kırıklar basit kırıklar, Tip A3 kırıklar parçalı kırıklardır. Kırık tipi ve kırığın oblikliği bu kırıkları dört alt tipe ayırır. Anteroposterior grafide transvers bir şekilde kırık hattı oluşturanlar iki gruba ayrılır: fleksiyon ve ekstansiyon tipleri. Fleksiyon tipinde, kırık hattı yüksekte ve anteriordadır ve distal fragman anteriora doğru ayrışır. Ekstansiyon tipinde, kırık hattı yüksekte posteriordadır ve distal parça posteriora yer değiş̧irir. Ek olarak, diğer iki grup olan adduksiyon ve abduksiyon tipi kırıklarda deforme edici kuvvete varus ve valgus kuvvetleri eklenir. ${ }^{[11]}$

\section{Cerrahi tedavi}

Eklem yüzü dahil olmadığı için bu tip kırıklarda konservatif tedavi ve perkütan K-teli ile tespit önerilmiştir. Perkütan K-teli ile tespit çocuklarda başarılı bir yöntemdir, erişkinlerde ve kemiğin osteopenik olduğu durumlarda bu yöntemle redüksiyon zordur. ${ }^{[12]} \mathrm{Bu}$ yüzden bikolumnar plaklama veya çok parçalı kırıklarda total eklem replasmanı daha stabil tercihlerdir. Hiç ayrışma göstermeyen ve anesteziyi kaldıramayacak yaşı hastalarda konservatif tedavi kullanılabilir; dört hafta kadar atelleme uygulanır. Yakın poliklinik kontrolü ve kırığın haftalık takibi yapılsa da, ilk iki hafta içinde genellikle kırıkta ayrışma görülür. Perkütan pinleme ve sonrasında atelleme yapılan erişkin hastalarda, bu tedavi stabiliteyi sağlamadığından tekrar yer değiştirme görülür ve cerrahi tedavi ihtiyacı doğar. Açık cerrahi tedavi olarak uygulanan teknik bikolumnar kırıklarda olduğu gibi açık redüksiyon ve çift plaklamadır.[13]

\section{Cerrahi teknik}

Hasta sırt üstü yatarken hafif oblik pozisyona alınarak, kol hastanın üstündeyken çalışılır veya hasta lateral pozisyonda iken kol tutucuya konur (Şekil 6). Greft gerekebileceği düşünülerek, otogreft kullanılacaksa uygun verici saha hazırlığı da yapılmalıdır. Turnike cerrahi kesi sahasının daha proksimaline konulmalıdır, kullanıldığı takdirde en fazla iki saat sonunda gevşetilmelidir. Metafiz uzanımlı çok parçalı kırıklarda turnike koyacak mesafe olmayabilir.

Cerrahi yaklaşım olarak posterior insizyon ile triseps olekranon üzerinde bırakılarak paratrisipital yaklaşım, veya posterior Bryan-Morrey trisepsi kaldıran yaklaşım ya da olekranon osteotomisi yapılarak transolekranon yaklaşımı (Şekil 7) kullanılabilir. ${ }^{[1,2]}$

Dirseğin ekstensör mekanizmasına zarar vermediği için paratrisipital yaklaşım, trisepsin her iki tarafına mediyal ve lateral pencere olarak yaklaşılabileceğinden eklem dışı distal humerus kırıklarında tercih edilen yöntem olmuştur. Bu yaklaşımın en büyük dezavantajı
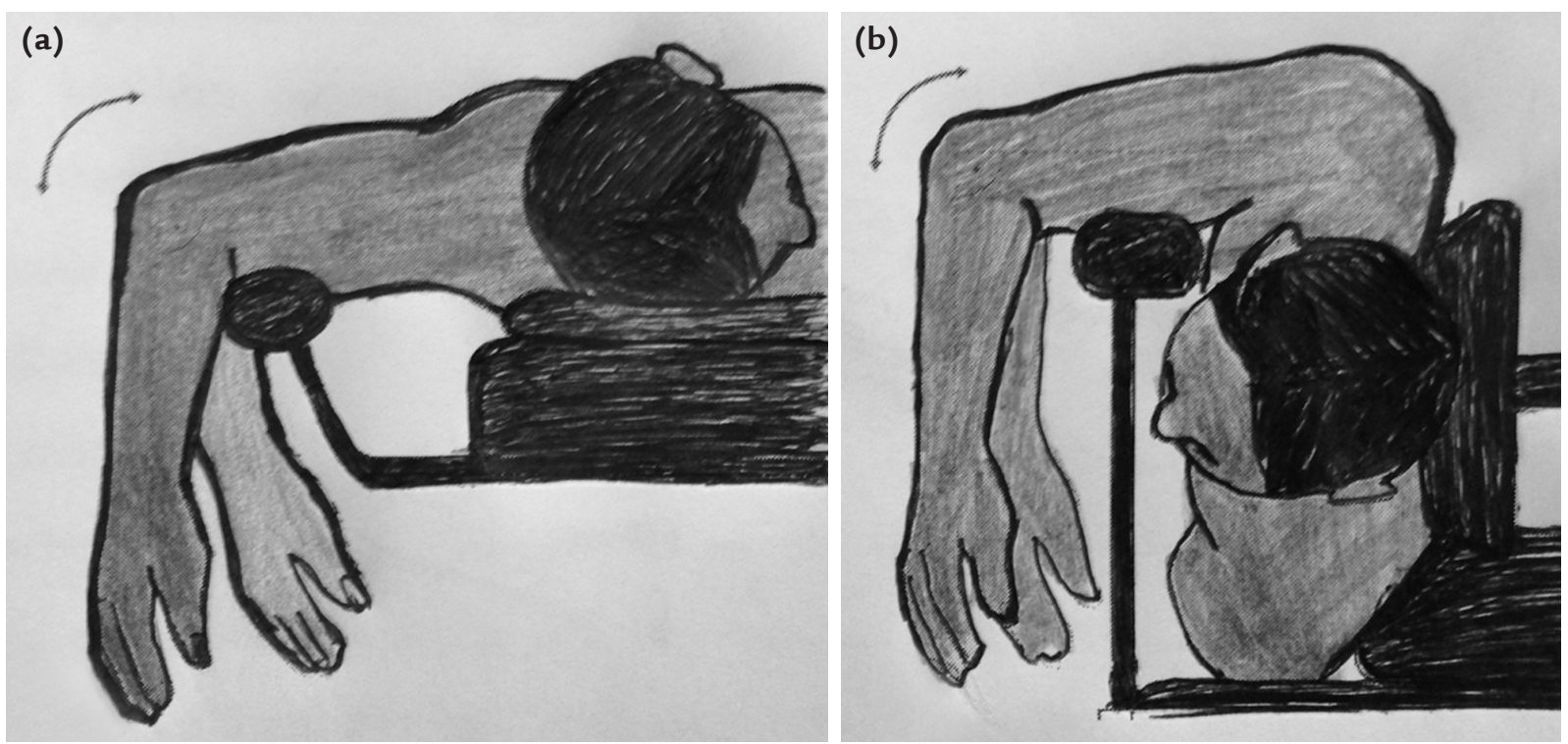

Şekil 6. a, b. Dirsek posterior girişim için yüzüstü pozisyon (a). Dirsek posterior girişim için lateral pozisyon (b). ${ }^{[14]}$ 

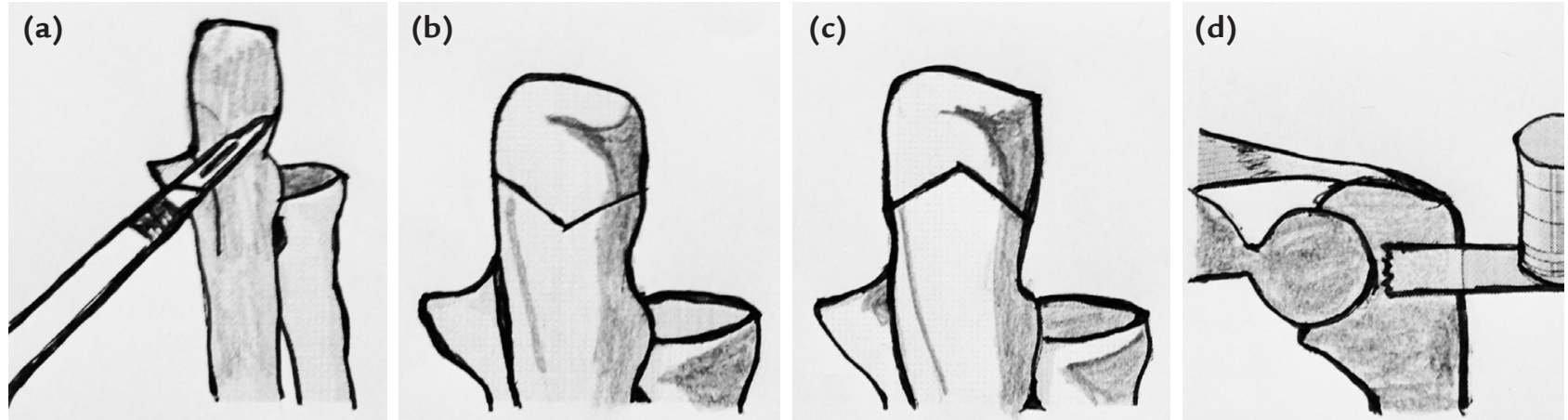

Şekil 7. a-d. Transolekranon osteotomisi (a), Chevron osteotomisi (b) veya Ters chevron osteotomisi (c) olekranon bölgesinden yapılabilir (d). ${ }^{[14]}$

eklem yüzeyinin sınırlı bir şekilde görülmesidir; fakat eklem dışı kırıklarda genellikle yeterli bir saha sağlar. ${ }^{[1,2]}$ Ayrıca bu yaklaşım ile gerek görüldüğgünde eklem içi olekranon osteotomisi de uygulanabilmektedir.

Tüm girişimlerde ulnar sinir ortaya konup korunmalıdır. Eklem dışı kırıklarda metafizyel parçalanma derecesine göre kırığın redüksiyonu zorlaşır. Metafizyel parçalar mümkün olduğu kadar anatomik redükte edilmelidir. Her fragman arası kompresyon ve temasın sağlanması stabilitenin ve ilerideki kaynamanın sağlanması için esastır. ${ }^{[2]}$ Bu nedenle bu tip kırıklarda triseps tendonunu kaldırarak (Şekil 8) veya transolekranon osteotomili yaklaşım (Şekil 7) daha iyi görüş sağlar.
Bu bölge kırıklarında tespitte mutlak stabilite sağlanmalıdır. Rijid tespit ve erken dirsek hareketlerine başlamada gereklidir. Plak uygulaması ve vida ile tespit anatomik redüksiyon elde etmek için çok önemlidir.

Birbirine dik açıyla (mediyal ve posterolateral) yerleştirilen çift plak tekniğinin bazı kırık tiplerinde yetersiz stabiliteye neden olduğu hem klinik hem de biyomekanik çalışmalar ile gösterilmiştir. ${ }^{[2,13,15,16]}$ Bu sorunu aşmak için, önceden şekillendirilmiş anatomik distal humerus plaklarını paralel plaklama tekniği geliştirilmiştir (Şekil 9 ve 10). ${ }^{[17]}$

Eklem yüzeyine komşu distal bölgede dizilimin sağlanması için gerekirse suprakondiler bölgeden kısaltma
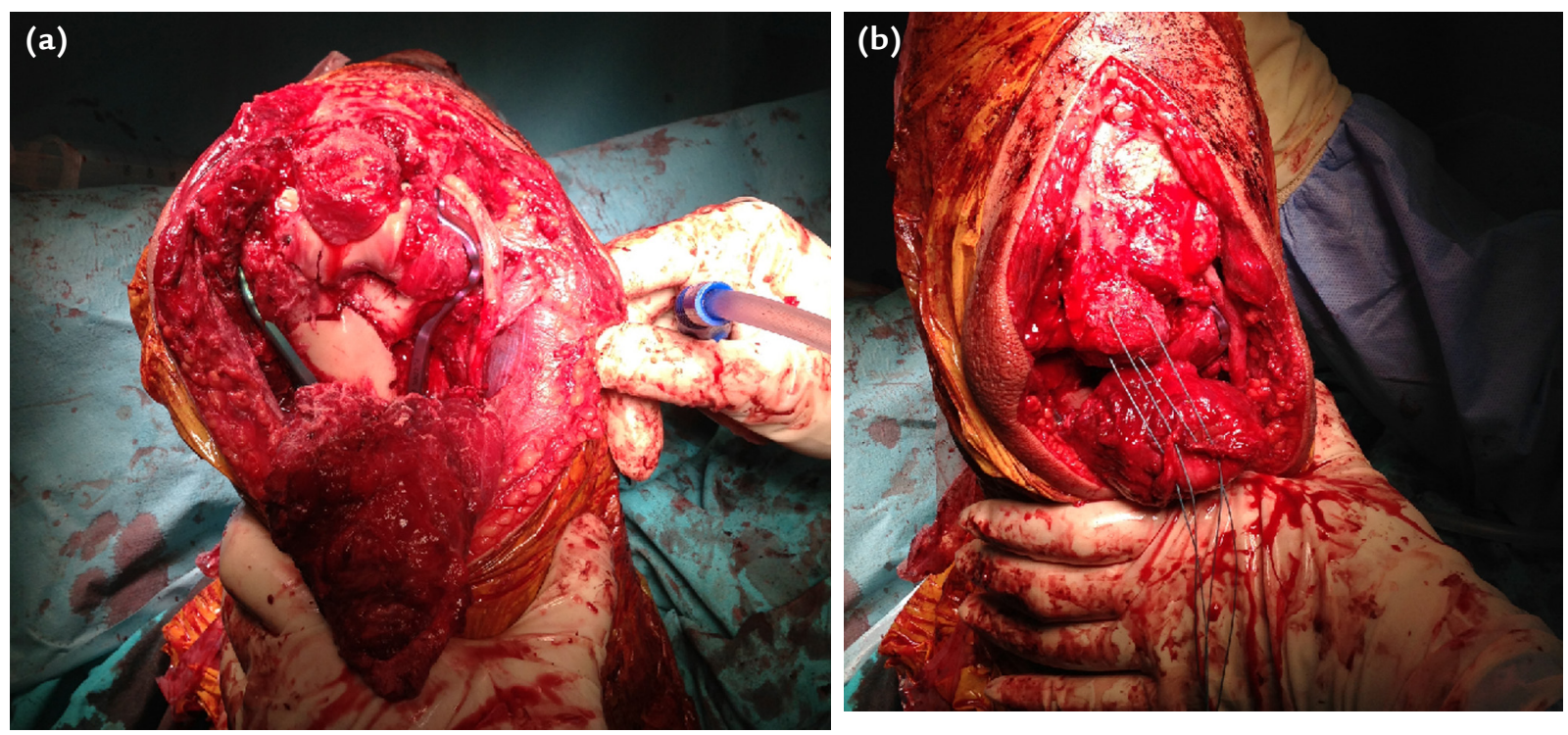

Şekil 8. a, b. Trisepsi kaldıran posterior Bryan-Morrey yaklaşımında triseps tendonu olekranon insersiyosundan sıyrılarak ayrılmıştır (a) ve mediyal ve lateralden paralel plaklama tekniği sonrası olekranona açılan deliklerden geçirilen sütürlerle triseps tendonu görülmektedir (b). 

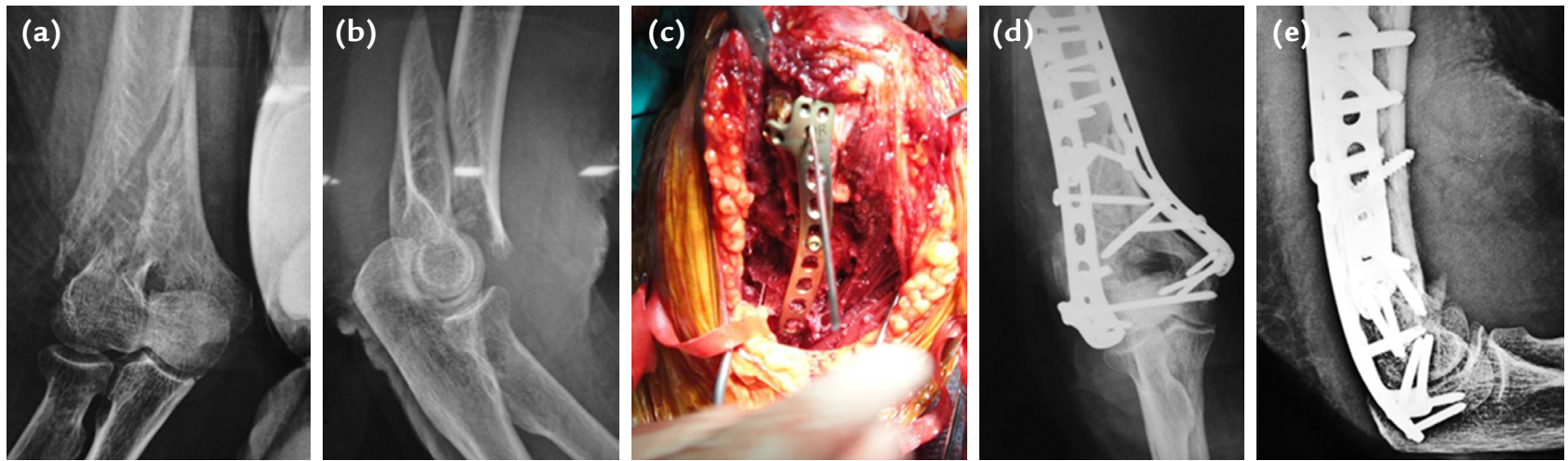

Şekil 9. a-e. Seksen iki yaşında kadın hasta AP ve lateral radyografilerde A 2.2 tip kırık görülmekte (a, b); Posterior trisepsi kaldıran insizyonla posterolateral ve mediyal dik plaklama tekniği uygulanmıştır (c); ameliyat sonrası AP ve lateral grafilerinde plak tespitleri görülmektedir (d, e).

(a)

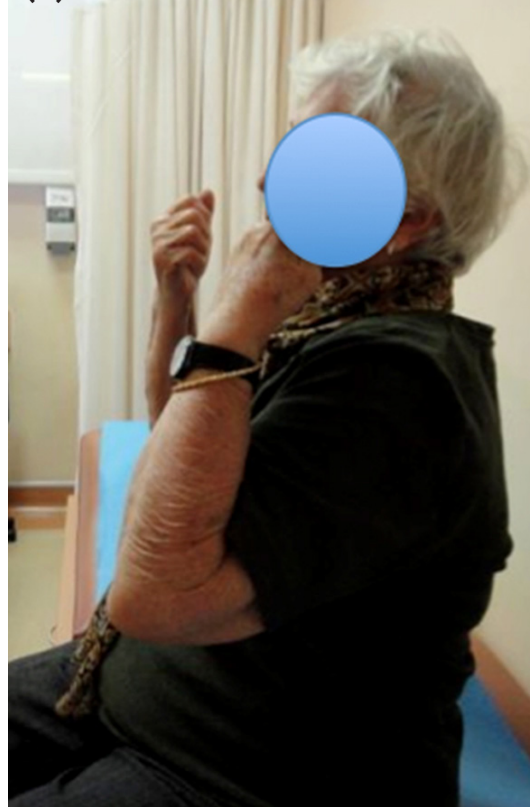

(b)

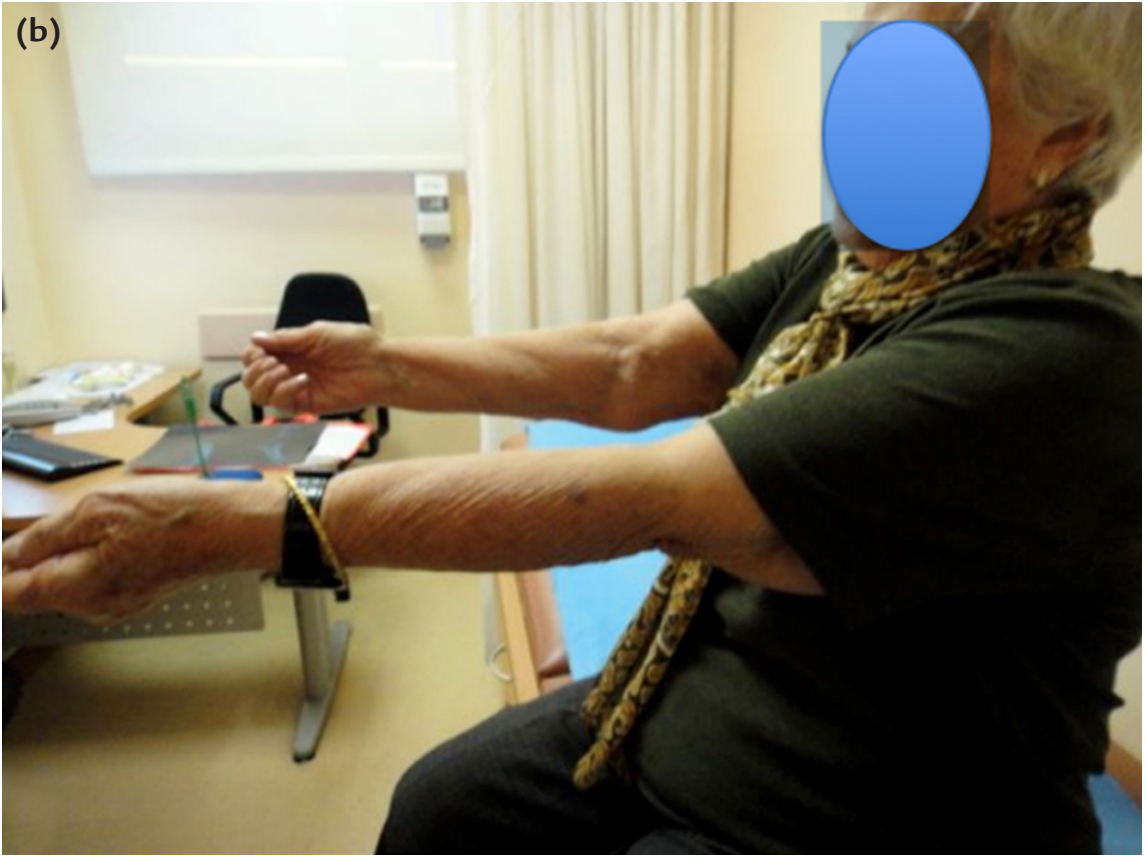

Şekil 10. a, b. Aynı hastanın ameliyattan iki ay sonraki eklem hareket açıklığı görülmektedir.

yapılabilir. Bir santimetre veya daha az kısaltmalarda fonksiyonda herhangi bir kayıp görülmediği, 2 cm'ye kadar olan kısaltmaların ise dirsek eklemi biyomekaniğinde ciddi bir rahatsızlığa neden olmadan iyi tolere edilebildiği gösterilmiştir. ${ }^{[18]}$

Mayo Anatomik Plakları (Mayo Clinic Congruent Elbow Plates, Acumed, Hillsboro, Oregon, USA) bu bölge kırıkları için uygun tespit materyalleridir. Sistemin yaratıcı ekibinin tarif ettiği prensiplere uygun şekilde, adım adım osteosentez sağlanmalıdır. ${ }^{[17,19]}$ Diyafiz parçası ile anatomik redüksiyon sağlanır ve epikondillerden diyafize çapraz 2,0 mm'lik iki adet K-teli ile geçici tespit yapılır. Çok parçalı kırıklarda Weber klempleriyle redüksiyon sağlandıktan sonra, geçici K-telleri ile tespit yapılır; gerekirse çektirme vidaları ile parçalar tespit edildikten sonra Weber klempleri ve K-telleri çıkarılır. Anatomik dirsek plakları kullanılırsa plak dirseğe rekonstrüksiyon plaklarından daha iyi oturacak ve anatomik redüksiyon daha rahat sağlanacaktır. ${ }^{[13]}$ Distal humerusun anatomik yapısına uygun kontur verilmiş olan plaklar, mediyal ve lateral kolona birbirlerine paralel şekilde yerleşirilmelidir. Plak boyu, kırığın proksimaldeki uzanımına göre, diyafiz parçasından en az üçer vida ile karşıııılı tespit sağlaması gereklidir; distal fragmana mümkün olduğunca uzun ve karşı kondile uzanacak 3,5 mm'lik karşıııkı birer vida, proksimal fragmana ise yine 3,5 mm'lik birer vida ile plaklar sabitlenmelidir. Daha sonra, suprakondiler bölgede kompresyonu sağlamak için, 
oval vida deliğinden eksentrik delik açılıp her iki kolonda kompresyon sağlanmalı. Distal fragmanlar her iki plaktan geçen ikişer, toplamda en az dört vida ile tespit edilmelidir. Proksimal fragmana da kırığın şekline göre karşılıklı en az üçer vida ile tespit tamamlanır. İleri osteoporotik kemiklerde ve metafizer parçalanması olan hastalarda, 2005 yılı sonundan itibaren kilitli vidalar da kullanılmıştır. ${ }^{[20,21]}$

Açık kırıklar ve ciddi yumuşak doku kaybı olan hastalarda eksternal fiksatör iyi bir şeçenektir.

Humerus alt uç kırıklarında tespit sorunlarının çoğu suprakondiler seviyededir. Eklemi içine alan distal parça ile humerus şaftı arasında metafizyel seviyede stabilitenin en üst düzeyde olmasına özen gösterilmelidir. Bunun için aşağıdaki 8 prensip yerine getirilmelidir. ${ }^{[22]}$

1. Tüm vidalar plaktan geçmelidir.

2. Her vida karşı taraf plakla tespit edilmiş fragmanı tutmalıdır.

3. Distal fragmana olabildiğince çok vida yerleştirilmelidir.

4. Her vida olabildiğince uzun olmalıdır.

5. Her vida olabildiğince çok eklem yüzeyi ile ilgili kırık parçayı tutmalıdır.

6. Her vida karşı taraf vidalarla kenetlenerek, tüm distal humerusa stabilite sağlayacak şekilde bir mimari oluşturmalıdır.

7. Plak, her iki kolonda kompresyon oluşturacak şekilde uygulanmalıdır.

8. Plak, kırık kaynayana kadar kırılma ve bükülmelere dayanacak kuwet ve sertlikte olmalıdır.

Kırık tespiti için kullanılan plak, proksimalde en az ikisi kilitli vida olacak şekilde üç vida yerleştirmeye izin verecek uzunlukta olmalıdır. ${ }^{[23]}$ Mümkün olduğunca tüm delikler vidalanmalıdır. Diyafizde tek korteks vidalama yeterli stabilite sağlar. Kortikal kalınlığın azaldığı metafizyel ve epifizyel bölgede vida boyu önemlidir. Mediyal (ulnar) kolon onarımında olekranon (arka) fossa ve koronoid (ön) fossadan vidaların geçilmesi potansiyel risktir. Eğer vida koronoid fossadan geçerse fleksiyon, olekranon fossasından geçerse ekstansiyon hareketi kısıtlanacaktır. Plak kemik uyumu iyi değilse, kompresyon vidası ile plak kemiğe yaklaştırılır. Gerekirse bu vida daha sonra kilitli vida ile değiştirilebilir, ancak osteoporotik kemiklerde vida değiştirme stabiliteyi azaltır. Kilitli ve kortikal vidalar birlikte kullanılacaksa, kortikal vidalar önce kullanılır. Aksi takdirde, önce kilitli vida ve daha sonra kortikal vida kullanılırsa vidaya ek yük biner. Ulnar plak trokleaya doğru uzatılıp yukarı doğru uzun bir vida yerleştirilir. ${ }^{[20]}$ Ulnar sinir irritasyonunu engellemek için ulnar sinirin transposizyonu gerekir.
Biyomekanik ve kadavra çalışmalarında, çok parçalı eklem dışı distal humerus kırıklarında, fizyolojik anterior, posterior ve lateral bending kuvvetlerine karşı çift plak uygulamasının, tek plak uygulamasından daha sıkı bir tespit sağladığı gösterilmiştir.[15,23,24] Schemitsch ve arkadaşları, O'Driscoll ve arkadaşlarının iki plak uygulamasının, kırık fragmanlarının arasında kortikal bağlantının olmadığı durumlarda da maksimum rijiditeyi sağladığını yayımlamışlardır. ${ }^{[15,23]}$ Sadece lateral kolona konulan tek bir plağın, mediyal buttress olmadan varus deformitesini engelleyemeyeceği ve varus baskılarına direncinin düşük olacağı tahmin edilebilir bir sonuçtur. Daha kalın ve geniş kilitli plak tasarımları bulunmaktadır. Bunlarla muhtemelen tespit rijiditesinde artış sağlanabilir fakat bununla ilgili bir yayın bulunmamaktadır. Sonuç olarak, literatürdeki görüş birliği; motorlu taşıt kazaları ve ateşli silahla yaralanmalarda sık gördüğümüz çok parçalı eklem dışı distal humerus kırıklarında çift plak uygulamasının, tek kilitli plak uygulamasına göre daha rijid tespit sağladığıdır. ${ }^{[15,23,24]}$

Ameliyat sonrası dorsalden breys uygulanabilir, dren çıkarıldıktan sonra pasif eklem hareketlerine izin verilir, ancak dirence karşı egzersize altı haftadan sonra başlanmalıdır. İmplantlar 12-18 aydan önce çıkarılmamalıdır. Illeri yaş hastalarda zorunluluk olmadıkça implant çıkarılması önerilmemektedir.

Dirsek ekleminde kalıcı sertlik, en sık görülen komplikasyondur. Dirseğin uzun süre hareketsiz bırakılması sonucu görülür. Suprakondiler seviyede kaynamama ikinci en sık görülen komplikasyondur. Diğer sık görülen komplikasyonlardan biri de kırık tespitinin yetersiz yapılmasına bağlı kaynamamadır (kaynamamaların \%75’i bu nedene bağlıdır). Kötü kaynama da görülebilir. Enfeksiyon nadirdir; bu durumda profilaktik antibiyotik verilir. Heterotopik ossifikasyon, özellikle gecikmiş tespit veya dirseğin pasif gerilmesi ya da kafa travması ile ilgili olarak oluşabilir. Travma sonrası osteoartroz ve ulnar nöropati de karşılaşılabilecek sorunlardandır. Bu karşılaşılan komplikasyonların nedenleri; kompleks eklem anatomisi, dirsek bölgesindeki ciddi kuvvetler, azalmış kemik mineral kalitesi ve primer stabilite yokluğudur. ${ }^{[20,25,26]}$

Sonuçların değerlendirilmesinde Cassebaum derecelendirmesi yararlı olacaktır. Buna göre fleksiyon ve ekstansiyonda $15^{\circ}$ 'den fazla kayıp olmadan ağrısız hareket mükemmel, $40^{\circ}-120^{\circ}$ arasındaki hareket arkı iyi, $110^{\circ}$ 'den az fleksiyon orta sonuç olarak kabul edilmiştir. Son çalışmalarda bu yöntemle değerlendirilen hastaların \%75-80'inden, en azından iyi sonuç almıştır. Humerus alt uç kırıkları zordur ve hiç kimse $\% 15$ 'ten daha az kötü sonuç alınabileceğini iddia edemez. ${ }^{[20,25]}$ 
Açık kırıklar ve ciddi yumuşak doku kaybının eşlik ettiği açık kırıklarda, osteoporoz yoksa eksternal fiksatör iyi bir seçenektir. Distal humerus (dirsek) seviye tespitinde K-tellerinden yararlanılmalıdır. Bu seviyede en stabil osteosentez, mediyal ve lateral kondillerden iki adet çapraz Schanz vidası ile mümkün olur. Bu seviyede ulnar sinir lezyonları sık görülebileceğinden, mediyalden mini insizyonla ulnar sinir ortaya konur ve korunup takibinde osteosentez yapılmalıdır. Dirsek çevresinde karbon çember kullanılacaksa, ameliyat sonunda dirsek eklemi hareketine izin verecek şekilde anterior bölüm kesilmelidir. Eğer metal çember kullanılacaksa, 5/8 çemberlerden yararlanılmalıdır. Oblik kırıklarda stoplu K-telleriyle interfragmanter kompresyon yapılmalıdır. Rotasyon merkezi bikondiler aksa denk gelmelidir. Menteşe, daha fazla stabilite sağlayan $19 \mathrm{~mm}$ parsiyel yivli civata ile yapilır. ${ }^{[27]}$

Yetersiz ve sağlam olmayan bir cerrahi tespitin revizyonu ilk ameliyata göre her zaman daha zordur. Fonksiyonel bir dirsek için erken aktif hareket, bunun için de güvenilir rijid tespit gereklidir. İyi bir cerrahi teknikle ve hasta uyumuyla, $\% 80$ iyi veya mükemmel klinik fonksiyonel sonuç elde edilebilir. ${ }^{[14]}$

\section{KAYNAKLAR}

1. Robinson CM. Fractures of the distal humerus. In: Rockwood CA, Bucholz RW, Court-Brown CM, Heckman JD, Tornetta P, editors. Rockwood and Green's fractures in adults. Vol 1. 6th ed. Philadelphia: Lippincott \& Williams; 2006. p. 1051-116.

2. Babacan $M$, Şeker $A$, Ünlü MC, Kesmezacar H. Humerus Distal Uç Kırıkları: Tanı Sınıflandırma, Klinik Değerlendirme ve Konservatif Tedavi. İçinde: Kesmezacar $\mathrm{H}$, editör. Omuz ve Dirsek Bölgesi Kırık ve Çıkıkları. İstanbul: Bayçınar Tıbbi Yayıncılık; 2010. s.89-103.

3. Muller ME. The comprehensive classification of fractures of long bones. In: Muller ME, Allgower M, Schneider R, et al., editors. Manual of internal fixation, 3rd ed. Berlin: Springer Verlag; 1991. p.118-50.

4. Orthopaedic Trauma Association Committee for Coding and Classification. Fracture and dislocation compendium. J Orthop Trauma 1996;10(Suppl 1):1-154.

5. Jawa A, McCarty P, Doornberg J, Harris M, Ring D. Extraarticular distal-third diaphyseal fractures of the humerus. A comparison of functional bracing and plate fixation. J Bone Joint Surg Am 2006;88(11):2343-7.

6. Smith FM. Medial epicondyle injuries. J Am Med Assoc 1950;142(6):396-402.

7. Durig M, Müller W, Rüedi TP, Gauer EF. The operative treatment of elbow dislocation in the adult. J Bone Joint Surg Am 1979;61(2):239-44.

8. Moon MS, Kim I, Han IH, Suh KH, Hwang JD. Arm wrestler's injury: report of seven cases. Clin Orthop Relat Res 1980;(147):219-21.

9. Kobayashi Y, Oka Y, Ikeda M, Munesada S. Avulsion fracture of the medial and lateral epicondyles of the humerus. J Shoulder Elbow Surg 2000;9(1):59-64.

10. Wilson JN. The treatment of fractures of the medial epicondyle of the humerus. J Bone Joint Surg Br 1960;42-B:778-81.
11. Amis AA, Miller JH. The mechanisms of elbow fractures: an investigation using impact tests in vitro. Injury 1995;26(3):163-8.

12. Swenson AL. The treatment of supracondylar fractures of the humerus by Kirschner-wire transfixion. J Bone Joint Surg Am 1948;30A(4):993-7.

13. Erdemli B. Humerus alt uç. İçinde: Rüedi TP, Murphy WM, Colton CL, Dell>Oca AF, Holz U, Kellam JF, Ochsner PE, editörler. Kırık tedavisinde AO kuralları. Ağuş $H$, çeviri editörü. İstanbul: Nobel Tıp Kitabevleri; 2006. s.307-20.

14. Helfet DL, Hotchkiss RN. Internal fixation of the distal humerus: a biomechanical comparison of methods. J Orthop Trauma 1990;4(3):260-4.

15. Schemitsch EH, Tencer AF, Henley MB. Biomechanical evaluation of methods of internal fixation of the distal humerus. J Orthop Trauma 1994;8(6):468-75.

16. Self J, Viegas SF, Buford WL Jr, Patterson RM. A comparison of double-plate fixation methods for complex distal humerus fractures. J Shoulder Elbow Surg 1995;4(1 Pt 1):10-6.

17. O'Driscoll SW, Sanchez-Sotelo J, Torchia ME. Management of the smashed distal humerus. Orthop Clin North Am 2002;33(1):19-33.

18. Hughes RE, Schneeberger AG, An KN, Morrey BF, O'Driscoll SW. Reduction of triceps muscle force after shortening of the distal humerus: a computational model. J Shoulder Elbow Surg 1997;6(5):444-8.

19. Sanchez-Sotelo J, Torchia ME, O’Driscoll SW. Complex distal humeral fractures: internal fixation with a principle-based parallel-plate technique. Surgical technique. J Bone Joint Surg Am 2008;90 Suppl 2 Pt 1:31-46. CrossRef

20. Kömürcü M, Uraş i, Yavuz OY. Distal humerus kırıklarında kilitli plak uygulamaları. TOTBiD Dergisi 2012;11(1):28-33.

21. Atalar AC, Demirhan M, Salduz A, Kılıçoğlu O, Seyahi A. Functional results of the parallel-plate technique for complex distal humerus fractures. Acta Orthop Traumatol Turc 2009;43(1):21-7. CrossRef

22. O'Driscoll SW. Optimizing stability in distal humeral fracture fixation. J Shoulder Elbow Surg 2005;14(1 Suppl S):186S-194S.

23. Mehling I, Schmidt-Horlohé K, Müller LP, Sternstein W, Korner J, Rommens PM. Locking reconstruction double plating of distal humeral fractures: how many screws in the distal ulnar column segment in A3 fracture provide superior stability? A comparative biomechanical in vitro study. J Orthop Trauma 2009;23(8):581-7. CrossRef

24. Tejwani NC, Murthy A, Park J, McLaurin TM, Egol $K A$, Kummer FJ. Fixation of extra-articular distal humerus fractures using one locking plate versus two reconstruction plates: a laboratory study. J Trauma 2009;66(3):795-9. CrossRef

25. Amis AA, Hughes $S$, Miller JH, Wright $V$, Dowson D. Elbow joint forces in patients with rheumatoid arthritis. Rheumatol Rehabil 1979;18(4):230-4.

26. Södergård J, Sandelin J, Böstman O. Postoperative complications of distal humeral fractures. 27/96 adults followed up for $6(2-10)$ years. Acta Orthop Scand 1992;63(1):85-9.

27. Kocaoğlu M. Travmatolojide Illizarov Uygulamaları. İçinde: Çakmak M, Kocaoğlu M. editörler. İlizaroz Cerrahisi ve Prensipleri. İstanbul: Doruk Grafik; 1999. p.183-208. 